\title{
Life Cycle Cost Analysis Comparing Redesigned CCHP to Existing Heat Pump Systems for Cities in Cold Climates - FY19 3rd Quarter Milestone Report
}

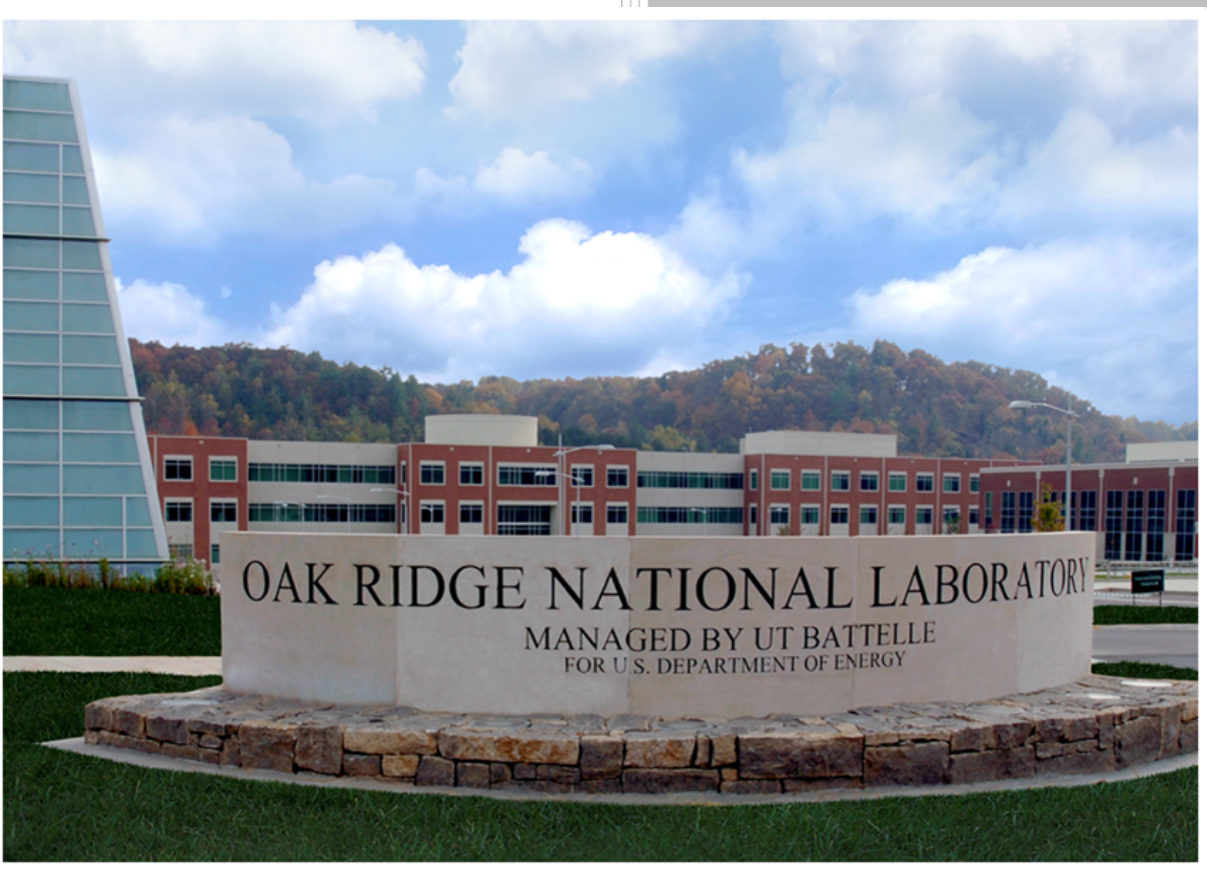

Approved for public release. Distribution is unlimited.

Bo Shen Jeffrey Munk 04/30/2019 


\title{
DOCUMENT AVAILABILITY
}

Reports produced after January 1, 1996, are generally available free via US Department of Energy (DOE) SciTech Connect.

Website http://www.osti.gov/scitech/

Reports produced before January 1, 1996, may be purchased by members of the public from the following source:

\author{
National Technical Information Service \\ 5285 Port Royal Road \\ Springfield, VA 22161 \\ Telephone 703-605-6000 (1-800-553-6847) \\ TDD 703-487-4639 \\ Fax 703-605-6900 \\ E-mail info@ntis.gov \\ Website http://www.ntis.gov/help/ordermethods.aspx
}

Reports are available to DOE employees, DOE contractors, Energy Technology Data Exchange representatives, and International Nuclear Information System representatives from the following source:

Office of Scientific and Technical Information

PO Box 62

Oak Ridge, TN 37831

Telephone 865-576-8401

Fax 865-576-5728

E-mail reports@osti.gov

Website http://www.osti.gov/contact.html

This report was prepared as an account of work sponsored by an agency of the United States Government. Neither the United States Government nor any agency thereof, nor any of their employees, makes any warranty, express or implied, or assumes any legal liability or responsibility for the accuracy, completeness, or usefulness of any information, apparatus, product, or process disclosed, or represents that its use would not infringe privately owned rights. Reference herein to any specific commercial product, process, or service by trade name, trademark, manufacturer, or otherwise, does not necessarily constitute or imply its endorsement, recommendation, or favoring by the United States Government or any agency thereof. The views and opinions of authors expressed herein do not necessarily state or reflect those of the United States Government or any agency thereof. 


\title{
BTO Project 1.2.2.70 \\ FY19 $3^{\text {rd }}$ Quarter Milestone Report
}

Life cycle cost analysis comparing redesigned CCHP to existing heat pump systems for cities in cold climates

\author{
Author \\ Bo Shen \\ Jeffrey Munk
}

Date: 04/30/2019

Prepared by

OAK RIDGE NATIONAL LABORATORY

Oak Ridge, TN 37831-6283

managed by

UT-BATTELLE, LLC

for the

US DEPARTMENT OF ENERGY

under contract DE-AC05-00OR22725 


\section{Life cycle cost analysis comparing redesigned CCHP to existing heat pump systems for cities in cold climates \\ (Go/No-Go Milestone)}

\section{Executive Summary}

This report indicates that the project progress has met the Go criterion, i.e. demonstrating favorable results of life cycle cost assessment for the redesigned CCHPs. Considering the market price of a baseline heat pump, and required improvements in heat exchangers, fans and an electronic expansion valve of the CCHPs, we estimated that the CCHP using a 3-stage scroll compressor will incur with a cost increment of \$386 per rated cooling tonnage, and the CCHP using tandem compressors will increase by $\$ 766$.

Based on the energy savings of the CCHPs, simulated by EnergyPlus, the two CCHPs achieve payback periods less than 5 years among all the cold climate cities. Within a typical heat pump life cycle of 20 years, the CCHPs can achieve cost savings around $\$ 2000$ to $\$ 3000$ per rated cooling tonnage, and the savings are even higher for the extremely cold cities like Duluth and Fairbanks. 


\section{TABLE OF CONTENTS}

Page

1. Cost Structures...

.5

2. Payback Periods and Life Cycle Cost Savings ................................................................... 


\section{List of Figures}

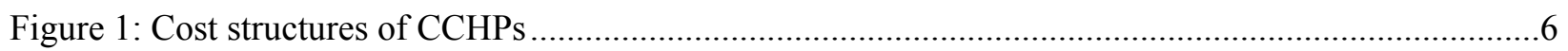

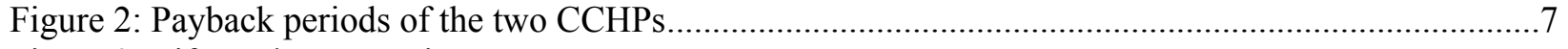

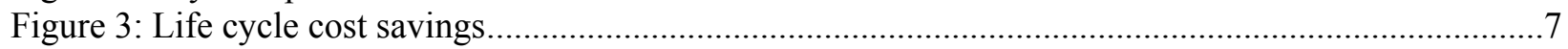




\section{LIST OF TABLES}

Table 1: Annual electricity consumptions and savings of multiple cold climate cities.

. .6 


\section{Cost Structures}

To replace baseline heat pumps having a rated cooling capacities of 3.5-ton and 3-ton, and SEER of 14.0. Two cold climate heat pumps (CCHPs) were evaluated in the past two milestone reports:

- Tandem heat pump: this unit uses tandem compressors, i.e. two parallel, identical, single-speed compressors, coupled with a two-speed indoor blower. Each single-speed compressor has a nominal capacity of $31 \mathrm{kBtu} / \mathrm{hr}$. The tandem heat pump gets its rated cooling capacity (the building design cooling load) with a single compressor at 3 -ton. The second compressor operates only for enhanced heating at low ambient temperatures, and is not used for cooling or for heating at ambient temperatures above $20^{\circ} \mathrm{F}$.

- 3-stage heat pump: this is a lower cost CCHP and has better cooling performance, which uses a 3-stage compressor and a two-speed indoor blower. The compressor stages are split to 50\%/67\%/100\%, having the $100 \%$ nominal capacity at $51 \mathrm{kBtu} / \mathrm{hr}$. The heat pump is rated at the $67 \%$ compressor capacity to get its rated cooling capacity of 3.5-ton, and the $100 \%$ compressor is used for enhanced heating at ambient temperatures below $20^{\circ} \mathrm{F}$. During cooling mode, the heat pump only operates its $50 \% / 67 \%$ compressor capacities.

To optimize the heating efficiency in a wide range of ambient temperatures, an electronic expansion valve will used to enable compressor discharge pressure control for both CCHPs.

With the information given in https://www.theacoutlet.com/, a whole sale website for AC/HP units. the baseline HP's price, before installation, is about $\$ 3100$ for a 3.5-ton HP, and \$2388 for a 3-ton HP, as shown in Figure 1. To achieve the CCHP's efficiency target, we will adopt heat exchangers and fan efficiency for a heat pump with a rated capacity of 5-ton and SEER of 16.0. In comparison to the 3.5-ton baseline HP, the cost increment in the heat exchangers, fans and the larger compressor is $\$ 1000$. And the cost increment is $\$ 1760$ for the 3-ton baseline HP. Using the parallel tandem compressors to replace the 2stage scroll compressor, the compressor cost increment is $\$ 400$. It is assumed that the new 3-stage compressor will incur with a $\$ 200$ cost increment in comparison to the 2-stage compressor in the 5-ton, 16 SEER HP. Additionally, given in https://www.zoro.com/, the cost of an electronic expansion valve at the rated capacity is about $\$ 150$. Therefore, the total cost increment for the CCHP using a 3-stage compressor, is $\$ 1350$ (\$386 per rated cooling tonnage), and \$2298 (\$766 per rated cooling tonnage) for the CCHP using the tandem compressors. These are overestimated cost increments, because manufacturers should pay much less to purchase the components when making the CCHPs in large qualities. 


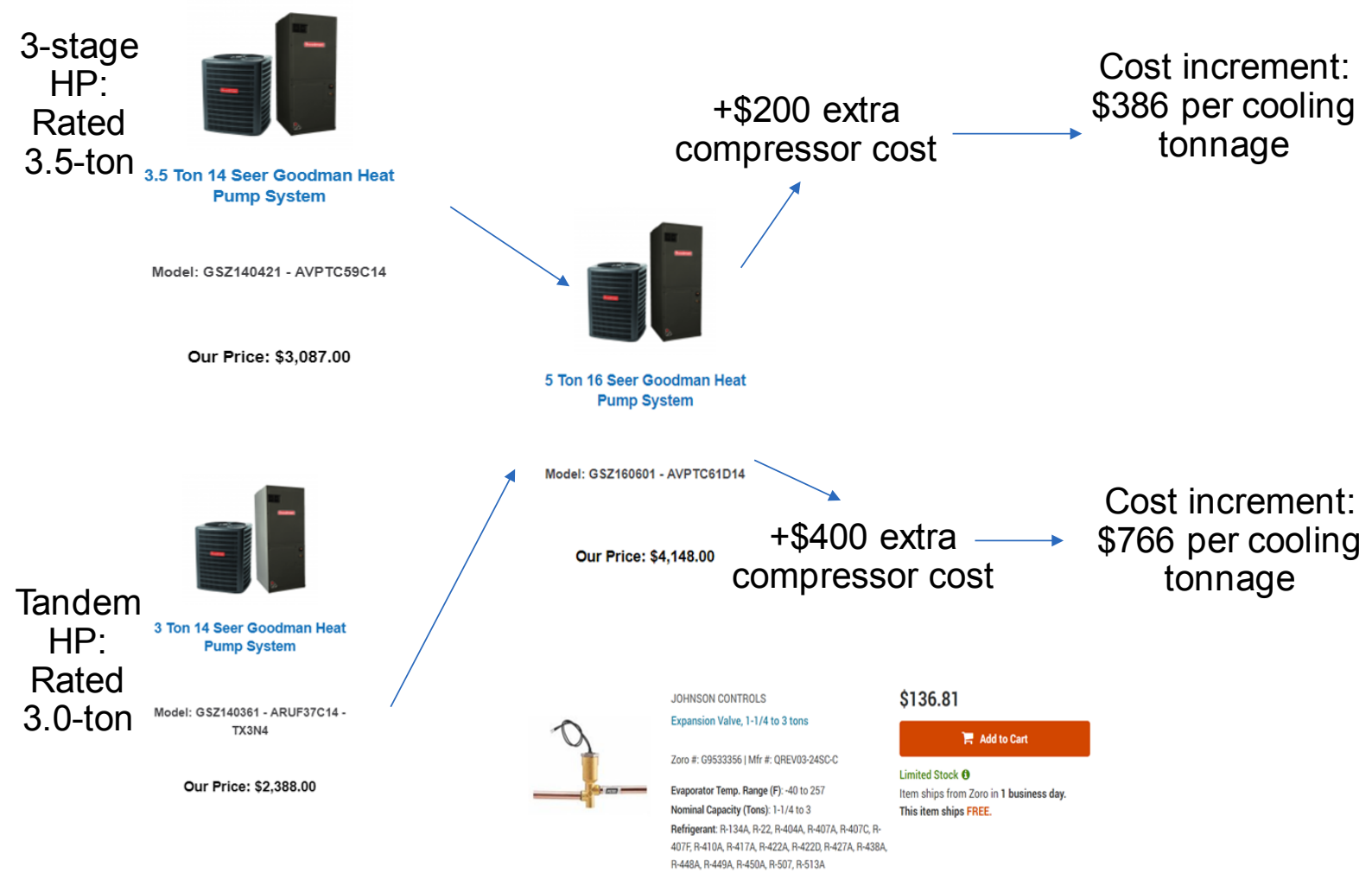

Figure 1: Cost structures of CCHPs

\section{Payback Periods and Life Cycle Cost Savings}

Table 1 reports total annual electricity consumptions $[\mathrm{kWh}]$ of the three heat pumps, and savings in $[\mathrm{kWh}]$ and dollars versus the baseline heat pump, per unit of rated cooling tonnage (building design cooling load) in the seven cold climate cities for a typical single-family house, simulated by EnergyPlus. It can be seen, savings in electricity are more evident in colder cities.

Table 1: Annual electricity consumptions and savings of multiple cold climate cities

\begin{tabular}{|c|c|c|c|c|c|c|c|}
\hline Total & Helena & Minneapolis & Duluth & Fairbanks & Eagle County & Peoria & Indianapolis \\
\hline 3-stage & 4912.6 & 4501.5 & 6779.5 & 11710.5 & 4686.4 & 4474.3 & 4434.0 \\
\hline Tandem & 4653.8 & 4326.2 & 6385.4 & 11303.7 & 4399.3 & 4241.3 & 4173.5 \\
\hline Baseline & 6046.4 & 5716.6 & 8554.0 & 14087.2 & 5838.8 & 5472.5 & 5493.4 \\
\hline \multicolumn{8}{|c|}{$\mathrm{kWh}$ annual savings per unit of rated cooling tonnage } \\
\hline 3-stage & 1133.8 & 1215.1 & 1774.6 & 2376.7 & 1152.4 & 998.2 & 1059.4 \\
\hline Tandem & 1392.6 & 1390.4 & 2168.7 & 2783.5 & 1439.5 & 1231.2 & 1319.9 \\
\hline \multicolumn{8}{|c|}{ Dollar annual savings per unit of rated cooling tonnage (per national average, $1 \mathrm{kWh}$ electricity costs 13 cents $^{1}$ ) } \\
\hline 3-stage & 147.4 & 158.0 & 230.7 & 309.0 & 149.8 & 129.8 & 137.7 \\
\hline Tandem & 181.0 & 180.8 & 281.9 & 361.9 & 187.1 & 160.1 & 171.6 \\
\hline
\end{tabular}

1. https://www.eia.gov/electricity/monthly/epm table_grapher.php?t=epmt 5_6_a 
Considering the cost savings per unit of rated cooling tonnage, payback periods of the two CCHPs are given in Figure 2, and the life cycle (20 years) cost savings are plotted in Figure 3.

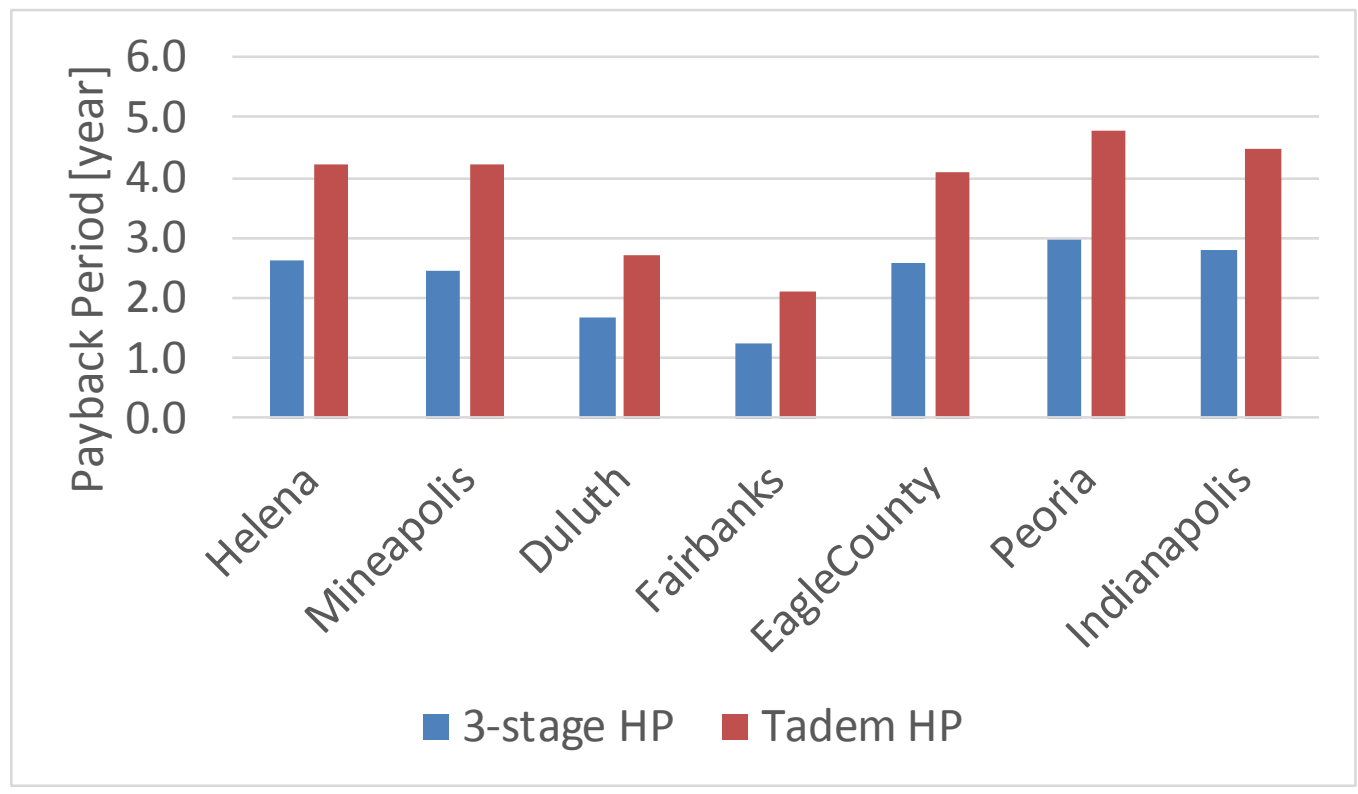

Figure 2: Payback periods of the two CCHPs

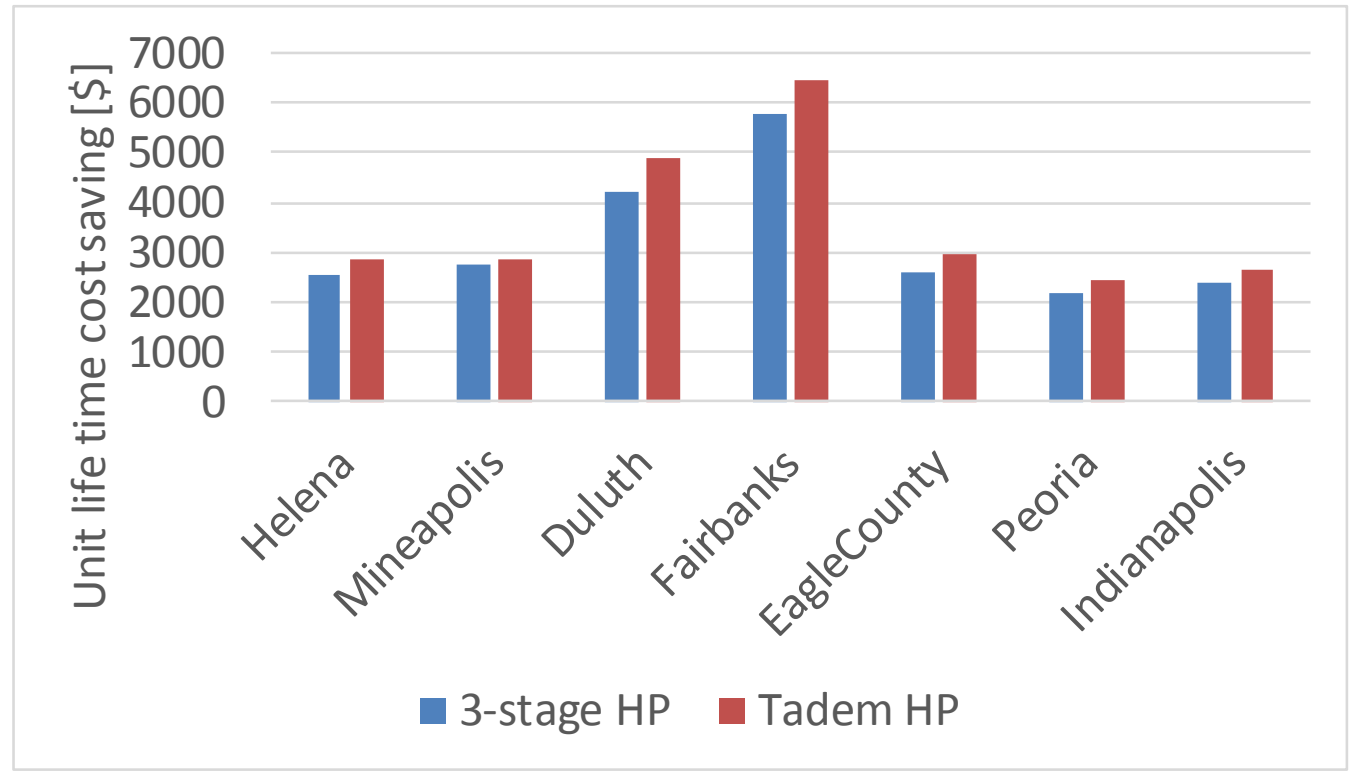

Figure 3: Life cycle cost savings

In all the cold climate cities, the two CCHPs achieve payback periods less than 5 years. For a typical heat pump life cycle of 20 years, the CCHPs can achieve cost savings around $\$ 2000$ to $\$ 3000$ per rated cooling tonnage, and the savings are even higher for the extremely cold cities like Duluth and Fairbanks. 